\title{
Effect of aluminum oxide nanoparticles on the rheology and stability of a biopolymer for enhanced oil recovery.
}

ORODU, K.B., AFOLABI, R.O., OLUWASIJUWOMI, T.D., ORODU, O.D. 
Title: Effect of Aluminum Oxide Nanoparticles on the Rheology and Stability of a Biopolymer for Enhanced Oil Recovery

Authors: Kale B. Orodu ${ }^{1}$, Richard O. Afolabi ${ }^{1,2}$, Toyosi D. Oluwasijuwomi ${ }^{1}$, Oyinkepreye D. Orodu $^{1 *}$

\title{
Affiliations:
}

${ }^{1}$ Department of Petroleum Engineering, Covenant University, Ota, Ogun State, Nigeria.

${ }^{2}$ Robert Gordon University, Aberdeen, UK.

*Contact email: oyinkepreye.orodu@covenantuniversity.edu.ng; preye.d.orodu@gmail.com

\begin{abstract}
Uncommon and untested biopolymers in field pilot studies, but applied in laboratory studies are combined with $\mathrm{Al}_{2} \mathrm{O}_{3}$ nanoparticles to form nanocomposites for enhanced oil recovery (EOR) performance evaluation. Core plug samples of the Niger Delta region and Berea sandstone were used as the porous media for EOR experiments. Incremental oil recovery sequel to waterflooding (secondary recovery) was $5-12 \%$ and $5-7 \%$ for potato starch nanocomposite (PSPNP) and gum arabic nanocomposite (GCNP) respectively. The biopolymer nanocomposites showed improved viscosity over the biopolymers. Thus, the nanoparticle served as a viscosity modifier on one-hand and stability enhancer on the other. EOR was affected by biopolymer and nanoparticle concentration with the attendant catch-22 situation of permeability impairment. The overall higher incremental recovery of applying PSPNP came by an intermediate potato starch (PSP) flooding between waterflooding and PSNP flooding. Consequently, slugs of biopolymer and biopolymer nanocomposite may be the way forward knowing that the biopolymers studied have surface-active constituents.
\end{abstract}

Keywords: Enhanced Oil Recovery, Biopolymers, Nanoparticles, Rheology

\section{Introduction}

Enhanced oil recovery (EOR) schemes otherwise referred to as tertiary recovery has been applied to go the extra mile of improving oil recovery (Hendraningrat et al., 2013a; Li et al., 2013). This sees recovery going beyond the primary means of the reservoir's in-situ energy, and secondary recovery that is commonly exploited by water and immiscible gas flooding. Recent research, albeit confined to laboratory scale testing for the oil and gas industry goes the way of innovative worldwide application of nanotechnology and miniaturised devices (Maghzi et al., 2012; Rousteai et al., 2012; Osamah et al., 2015). The focus is now on functionalized nanoparticles for the control of matter at the nanoscale level (Hendraningrat et al., 2013b; Sun et al., 2017). Nanoparticle retention has been a subject for concern. Nanoparticle adsorption onto solid surfaces may impede nanoparticle transport even for nanoparticles of appropriate size, shape, and good stability (Rodriguez et al., 2009). Adsorption of nanoparticles mainly takes place due to interactions of chemicals and rock surfaces through hydrogen bonding, hydrophobic bonding, and covalent bonding (Hendraningrat et al., 2013a; Hendraningrat et al., 2013b). There is a need to prevent these interactions by changing some occurring phenomenon in the system. This has necessitated the use of polymer-coated nanoparticles. The polymer flooding technology for EOR can be classified as a proven technology due to its wide field application in recent years (Abidin et al., 2012). Hydrolyzed Polyacrylamide (HPAM) and 
Carboxyl Methyl Cellulose (CMC) have been used over the years in the displacement of crude oil from reservoirs. The use of polymers in flooding operations is to reduce mobility when dissolved in water (Abidin et al., 2012; Yousefvand and Jafari, 2015). The increase in viscosity is responsible for the reduction in oil/water mobility ratio. This is achieved by an increase in the polymer concentration in aqueous solution ( $\mathrm{Yu}$ et al., 2010; Ogolo et al., 2012; ShamsiJazeyi et al., 2014). HPAM is the most widely used polymer for EOR operations, and this is due to its low price and good rheological properties. Furthermore, the procedure for implementing EOR schemes involving the use of HPAM is less difficult, and oil recovery is significantly improved under standard reservoir conditions (Abidin et al., 2012). However, there are limitations to the increment in the concentrations of the polymers. It has been reported that increment of more than $10 \%$ in the case of CMC adversely affects the displacement of oil (Abidin et al., 2012). Furthermore, CMC becomes poorly miscible with water at concentrations greater than $10 \%$ thereby making the injection into reservoirs difficult. The use of HPAM has its drawbacks as well; with reported cases of degradation under high temperature (usually above $99{ }^{0} \mathrm{C}$ depending on brine hardness) and sensitivity to salinity, precipitation occurs if $\mathrm{Ca}^{2+}$ and $\mathrm{Mg}^{2+}$ are present (Abidin et al., 2012; Lewandowska, 2006). However, the recent study on HPAM-based silica nanocomposite has brought improvement on HPAM application in high temperature and high salinity environment (Hu et al., 2017). The use of biopolymers such as xanthan gum has proven to perform well in high salinity brine and compatible with most injected fluid additives for EOR operations. Besides its salinity resistance, new techniques have been reported which improves the thermal stability of biopolymers up to $105^{\circ} \mathrm{C}$. Moreover, such polymers produced as either broth or concentrate form can be made to working concentrations without the need for elaborate shear mixing equipment. Advancement in nanotechnology has shown that the use of nanoparticles in polymer flooding operations can increase the oil recovery factor (Yousefvand and Jafari, 2015; Saha et al., 2018). There exist a few pieces of research about biopolymer performances in the presence of nanoparticles (Abidin et al., 2012; ShamsiJazeyi et al., 2014) for enhanced oil recovery. In this work, the effect of alumina nanoparticles on oil recovery during polymer flooding by biopolymers is investigated. The biopolymers considered include the naturally occurring Gum Arabic and an experimentally derived biopolymer from potatoes peels. The rheology of the polymer nanocomposite was investigated under high temperature and salinity.

\section{Materials and Method}

\subsection{Materials}

Laboratory grade Sodium Chloride $[\mathrm{NaCl}]$ was used to prepare brine and Acetone $\left[\mathrm{C}_{3} \mathrm{H}_{6} \mathrm{O}\right]$ for core cleaning. Core plugs of the Offshore Depobelt - Niger Delta (Niger Delta consist of five depobelts which are Northern, Greater Ughelli, Coastal Swamp 1 \& 2 and Offshore) were acquired for core flooding. Also, Berea sandstone cores were purchased from Cleveland Quarries Inc. Other materials are crude oil of $34.97{ }^{\circ} \mathrm{API}$ from the Niger Delta (Izombe Oilfield, OML 124), Polymer (Gum Arabic), $\mathrm{Al}_{2} \mathrm{O}_{3}(30-60 \mathrm{~nm}$, purity greater than $99 \%$; manufactured by Sigma Aldrich and purchased from Equilab Solutions in Nigeria), Gum Arabic polymer and potato peels. Potatoes used were purchased at Ota, Nigeria $\left(7.95^{\circ} \mathrm{N}, 4.783^{\circ} \mathrm{E}\right)$ and Gum Arabic from Kaduna, Nigeria $\left(10^{\circ} 31^{\prime} 23^{\prime \prime} \mathrm{N}, 7^{0} 26^{\prime} 25^{\prime \prime} \mathrm{N}\right)$. Deionised water was used as the base fluid for nanoparticle and polymer to formulate nanofluid and polymer solutions respectively. The equipment used for core flooding and viscosity is OFITE ${ }^{\circledR}$ 's reservoir permeability tester (RPT) and OFITE ${ }^{\circledR}$ 's direct indicator viscometer (8-speed). Other equipment includes Vinci Equipment's high-pressure core saturator (used for initial saturation of core plugs with brine), pycnometer (used for measuring crude oil density), desiccator (used for storing cleaned and dried cores), Soxhlet apparatus (used for cleaning the cores of crude oil and formation brine) etc. 


\subsubsection{Potato Starch}

Potato starch forms paste having high viscosity. The high viscosity endears it as a possible agent for enhanced oil recovery since the mobility ratio of the displacement process is reduced. Other properties are its binding capacity and formation of gel within $50-80{ }^{\circ} \mathrm{C}$ (Herrera et al., 2017; LeCorre et al., 2012). The gelatinisation temperature has and can be modified (Oosten, 1982) to ensure its use within the confines of petroleum reservoir temperature. Potato starch contains amylose and amylopectin. Minor components include protein and lipids in relatively small amounts. The most common application of starch is in the food industry just like gum arabic.

Weight averaged molecular (Mwt) and standard deviation (SD) of a typical native starch for potato is 2.305E-06 g/mol and 0.004E-06 respectively (Bidzinska et al., 2015). The Mwt from potato starch peel used in this study was not measured, it is noted that there are merits and demerits of various techniques available for the measurement of the Mwt of starch (Harding et al., 2016). Furthermore, it is essential to note that any two starch that has the same Mwt and different SD will have different rheological properties (Gilbert et al., 2010).

\subsubsection{Gum Arabic}

Gum Arabic (GA) is a gum exudate produced by Acacia senegal and Acacia seyal trees. It is known as an emulsifying agent for the food industry primarily. The constituents are mainly arabinogalactan (AG), arabinogalactan protein (AGP) and glycoprotein (GP) in the average proportions of $\approx 90 \%, \approx 10 \%$, and $\approx 1 \%$ (Mahendran et al., 2008; Renard et al., 2006). The molecular structure and composition of GA and its biophysical properties of Acacia Senegal from Nigeria were investigated by Gashua (2016). Transmission electron microscopy (TEM) analysis showed varied macromolecules of size from 12 to $60 \mathrm{~nm}$ (Tan, 2004). The properties of GA endearing its use in the food industry are due to the emulsification, microencapsulation, thickening and stabilisation capability. AGP fraction of GA possess the emulsifying property, and GA is soluble in water. This capability is contributed to by the hydrophilic sugar residues and the hydrophobic amino acids and so latches on to the oil-water interface (Degean et al., 2012). These substances are the hydrophilic polysaccharide (sugar residues) and hydrophobic polypeptide chains (Buffo et al.,2001)

\subsection{Polymer and Polymer-Nanocomposite Preparation}

The starch used in the biopolymer preparation was extracted from the potato peel. $120 \mathrm{~g}$ of potato peel was washed and grated into smaller sizes. The grated potato peels were added to $350 \mathrm{ml}$ of water after which it was blended for 15 minutes. The blended potato peels were sieved leaving the larger sizes of potato starch behind. The sieved mixture was allowed to settle for 8 hours. The settled mixture was decanted to obtain the starch at the bottom of the mixture. The obtained starch was air dried for 20 hours to remove any form of moisture present.

Starch polymer preparation involves: (a) distilled water added to starch at specific concentration and (b) pre-gelatinised starch prepared by slowly heat solution to $60{ }^{\circ} \mathrm{C}$ with continuous stirring made possible by a magnetic stirrer.

Gum Arabic (GA) solution was prepared with deionised and then aged for 5 days at room temperature. $\mathrm{Al}_{2} \mathrm{O}_{3}$ nanofluid was likewise prepared with deionised water. GAnanocomposite (GCNP) came up by blending to give $3 \mathrm{wt} \% \mathrm{GA}$ and $1.33 \mathrm{wt} \% \mathrm{Al}_{2} \mathrm{O}_{3}$, and $5 \mathrm{wt} \% \mathrm{GA}$ and 1.33 $\mathrm{wt} \% \mathrm{Al}_{2} \mathrm{O}_{3}$ solution. Similarly, Potato Peel Starch Polymer Nanocomposite (PSPNP) of $5 \mathrm{wt} \%$ potato starch (PSP) and $0.5 \mathrm{wt} \% \mathrm{Al}_{2} \mathrm{O}_{3}, 5 \mathrm{wt} \% \mathrm{PSP}$ and $1.0 \mathrm{wt} \% \mathrm{Al}_{2} \mathrm{O}_{3}, 5 \mathrm{wt} \%$ PSP and 1.5 


\section{5}

156

wt $\% \mathrm{Al}_{2} \mathrm{O}_{3}$ respectively. Also, the solutions for PSPNP were generated at two saline concentrations of $2.5 \mathrm{wt} \%$ and $5.0 \mathrm{wt} \%$. The choice of polymer concentration of Gum Arabic and Potato Starch arose from the works of Taiwo and Olafuyi (2015) with the use of $5 \mathrm{wt} \%$ GA polymer slug. Other considerations were interfacial tension (IFT) reduction by polymeric nanofluid with nanoparticle concentration of $1.5 \mathrm{wt} \%$ and $2.0 \mathrm{wt} \% / \mathrm{v}$ (Mauryu et al., 2017; Sharma and Sangwai, 2017) and wettability alteration based on an optimal nanoparticle concentration of $2-3 \mathrm{wt} \%$ (Ju and Fan, 2009).

\subsection{Rheology}

Measurement of parameters for the computation of viscosity in base on the tabulated process in Table 1

Table 1 - Scheme for Measurement of Rheological Properties

\begin{tabular}{|c|c|c|c|}
\hline $\mathbf{S} / \mathbf{N}$ & Experiment & Starch & Gum Arabic \\
\hline 1. & Aging of the polymer at ambient condition & $\approx 48 \mathrm{hrs}$ & 24 hrs \\
\hline 2. & $\begin{array}{l}\text { Heating of polymer and intermittent stirring before } \\
\text { Viscosity measurement (dial reading at each speed) } \\
\text { *different polymer blend for each speed }\end{array}$ & $15-20$ mins & $5-10$ mins \\
\hline 3. & Stable dial reading & 2 mins & 2 mins \\
\hline
\end{tabular}

At each temperature of $50{ }^{\circ} \mathrm{C}, 100{ }^{\circ} \mathrm{C}$, and $150{ }^{\circ} \mathrm{C}$, the sample polymer (and polymer nanocomposite) was heated $10{ }^{\circ} \mathrm{C}$ above the specified temperature as the measurement of viscosity was not done simultaneously with heating the polymer.

\subsection{Experimental Core Flooding}

Core samples were cleaned with acetone in a Soxhlet apparatus to remove oil and existing salt and dried in an oven at a controlled temperature, followed by being stored in a desiccator. The samples were weighed and saturated with prepared brine (3 wt.\%) by the use of a saturator for computation of porosity and pore volume. Fluid density and viscosity were measured with pycnometer and glass capillary viscometer. Core flooding was conducted with OFITE's Reservoir Permeability Tester (RPT). The schematic of the coreflood setup is as shown in Figure 1. All flooding experiments were performed at ambient condition, and the differential pressure was measured across the core holder. The core flooding scheme progressed by the initial saturation of core at $3 \mathrm{wt} . \%$ brine. This is a primary imbibition process followed sequentially by a drainage process to displace the brine. Oil was used to displace the brine at a specific rate until no brine was produced anymore. 


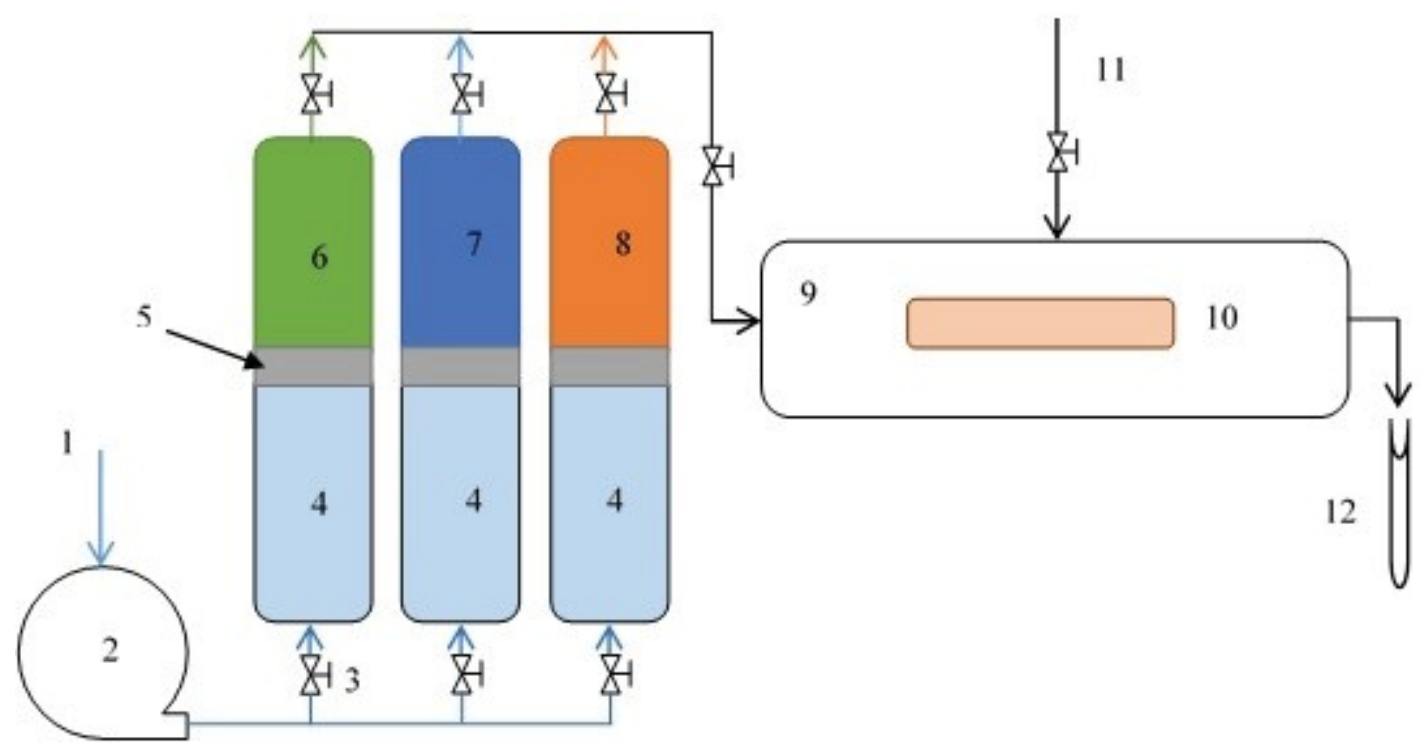

Figure 1 - Schematic of the core flooding apparatus (OFITE reservoir permeability tester). 1) fluid supply, 2) 515 HPLC pump, 3) valves, 4) water, 5) drive piston, 6) crude oil, 7) brine, 8) polymer or nanocomposite, 9) Hassler cell holder, 10) core plug, 11) confining pressure, 12) test tube for effluent.

The primary drainage procedure gave rise to the initial water saturation and followed by the injection of brine to recover oil; this is widely referred to as waterflooding (secondary recovery). The latter process achieved residual oil saturation by waterflooding. Polymer and/or nanocomposite flooding were initiated as a tertiary process (EOR) to investigate possible oil recovery after the waterflooding process. The likely incremental oil produced will ascertain the potential of polymer and/or nanocomposite as a viable tertiary recovery scheme. Since the flooding experiment was not automated, monitoring of the entire sequence of operation was done. A sampling of the effluent fluids was done every 5 minutes at the outlet of the core holder. This is a manual process, which enabled the measurement of produced oil, and brine for computation of core saturation and the recovery factor of the secondary and tertiary recovery processes.

\section{Results and Discussion}

\subsection{Effect of Salinity and Temperature on the Rheology of Biopolymer Nanocomposites}

\subsubsection{Potato Peel Starch Polymer Nanocomposite(PSPNP)}

Biopolymer nanocomposite (PSPNP) solution (400 ppm) is made in the brine of various salinities $(28.57 \mathrm{~g} / \mathrm{L}-2.5 \mathrm{wt} \%$ and $57.14 \mathrm{~g} / \mathrm{L}-5.0 \mathrm{wt} \%)$ and the relationship between the viscosity and shear rate at $50^{\circ} \mathrm{C}, 100^{\circ} \mathrm{C}$, and $150^{\circ} \mathrm{C}$ is shown in Fig 2a-c below. Fig. 2c show no significant effect of salinity on the viscosity of the biopolymer but exhibits shear-thinning behaviour for all salinities. This is because of the biopolymers non-ionic nature and tolerance of molecules. This non-ionic nature tends to improve the viscosity of the biopolymer regardless of the salinities.

The PSPNP solution was heated to at varying Temperature $\left(50^{\circ} \mathrm{C}, 100^{\circ} \mathrm{C}, 150^{\circ} \mathrm{C}\right)$ respectively. The viscosity was measured using the viscometer. The viscosity of the PSPNP slightly declined when temperature increased, From Fig $3 \mathrm{a}$ and $3 \mathrm{~b}$ at a temperature of $50^{\circ} \mathrm{C}$ the viscosity of the PSPNP was increasing and showed stability between $50^{\circ} \mathrm{C}$ to $120^{\circ} \mathrm{C}$ and degrades afterwards 

at $150^{\circ} \mathrm{C}$. The heat resistant property of PSPNP is possibly attributed to its complex structure. It did not affect the nanoparticle $\left(\mathrm{Al}_{2} \mathrm{O}_{3}\right)$

207 

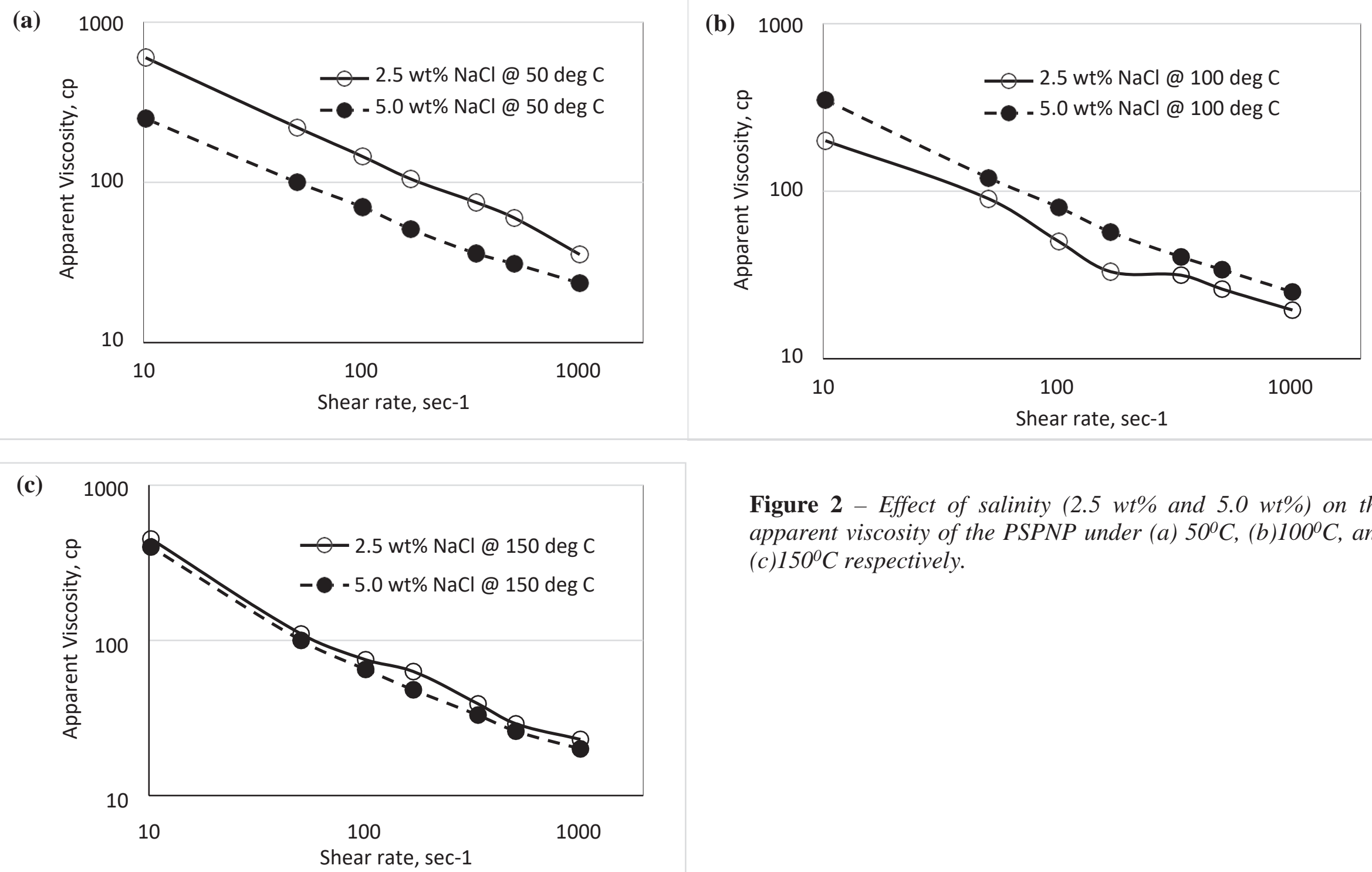

Figure 2 - Effect of salinity (2.5 wt\% and $5.0 w t \%)$ on the apparent viscosity of the PSPNP under (a) $50^{\circ} \mathrm{C}$, (b) $100^{\circ} \mathrm{C}$, and (c) $150^{\circ} \mathrm{C}$ respectively. 

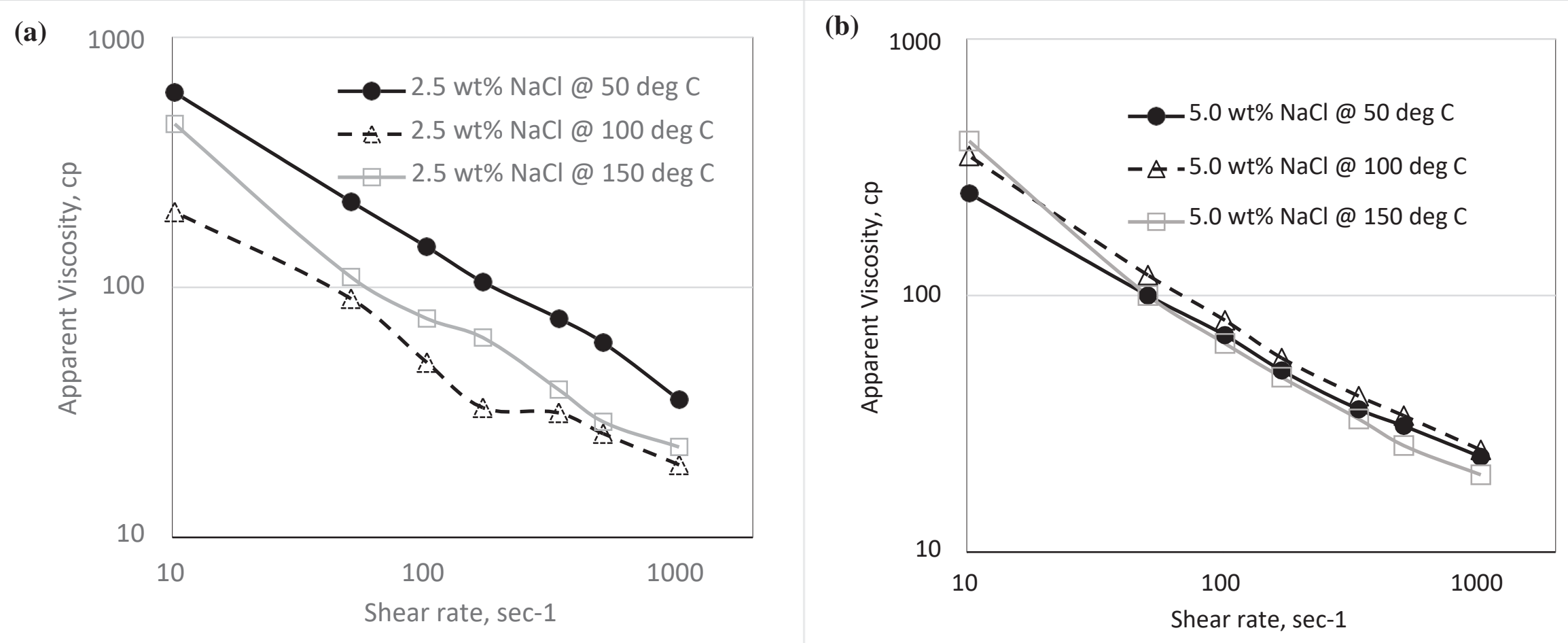

Figure 3 - Effect of temperature $\left(50^{\circ} \mathrm{C}, 100^{\circ} \mathrm{C}\right.$, and $\left.150^{\circ} \mathrm{C}\right)$ on the apparent viscosity of the PSPNP under (a) 2.5 wt\% and (b) 5.0 wt\% salinity respectively. 
215 Temperature effects on the rheology of dispersions containing Gum Arabic Nanocomposite (GCNPs) and Gum Arabic (GA) polymer showed relative stability in the viscosity of the

217 dispersion containing GCNPs compared to GA. Also, the improvement in the rheological

218 behaviour of the GCNPs dispersions when compared to Gum Arabic polymer could be tied to

219 the associative interaction between polymer and nanoparticles. The associative interaction

220 between the nanoparticle and polymer improve the gelling characteristics of the GCNPs. Figure

2214 displays graphically, the viscosity profile for GA and the impact of $\mathrm{Al}_{2} \mathrm{O}_{3}$ on GA (GA

222 nanocomposites). Furthermore, the impact of temperature at 25, 50, 100 and $150{ }^{\circ} \mathrm{C}$ on the

223 nanocomposite is shown in Figure 5. These graphs and other accompanying dataset had earlier on been presented in Orodu et al. (2018a) without discussion of observed trends. 

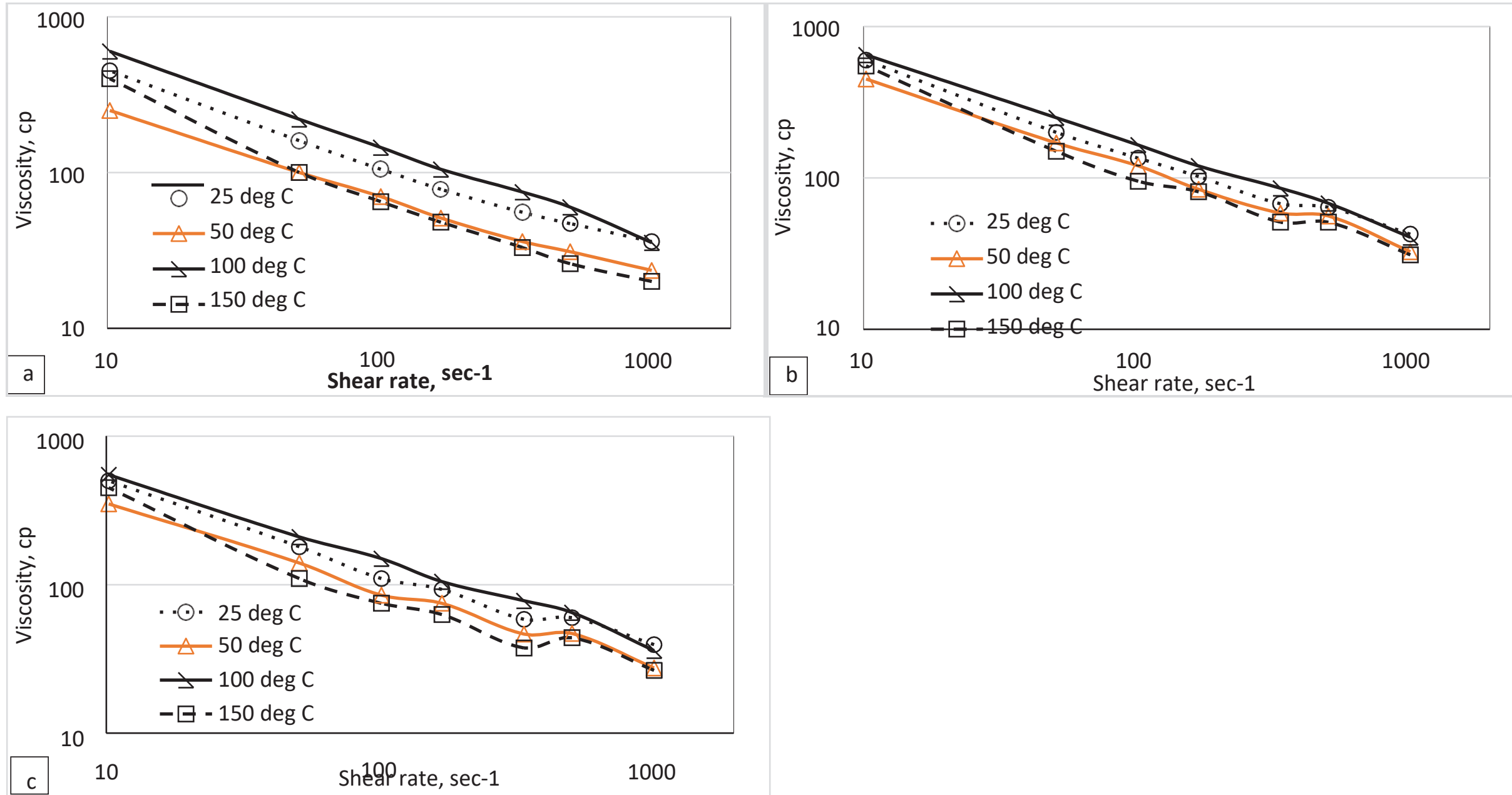

Figure 4 - Viscosity profile for (a) GA (1.33wt.\%) polymer solution (b) GCNPs (1.33wt.\% GA-5wt.\% Nanoparticles) (c) GCNPs (1.33wt.\% GA230 5wt.\% Nanoparticles (Orodu et al., 2018) 

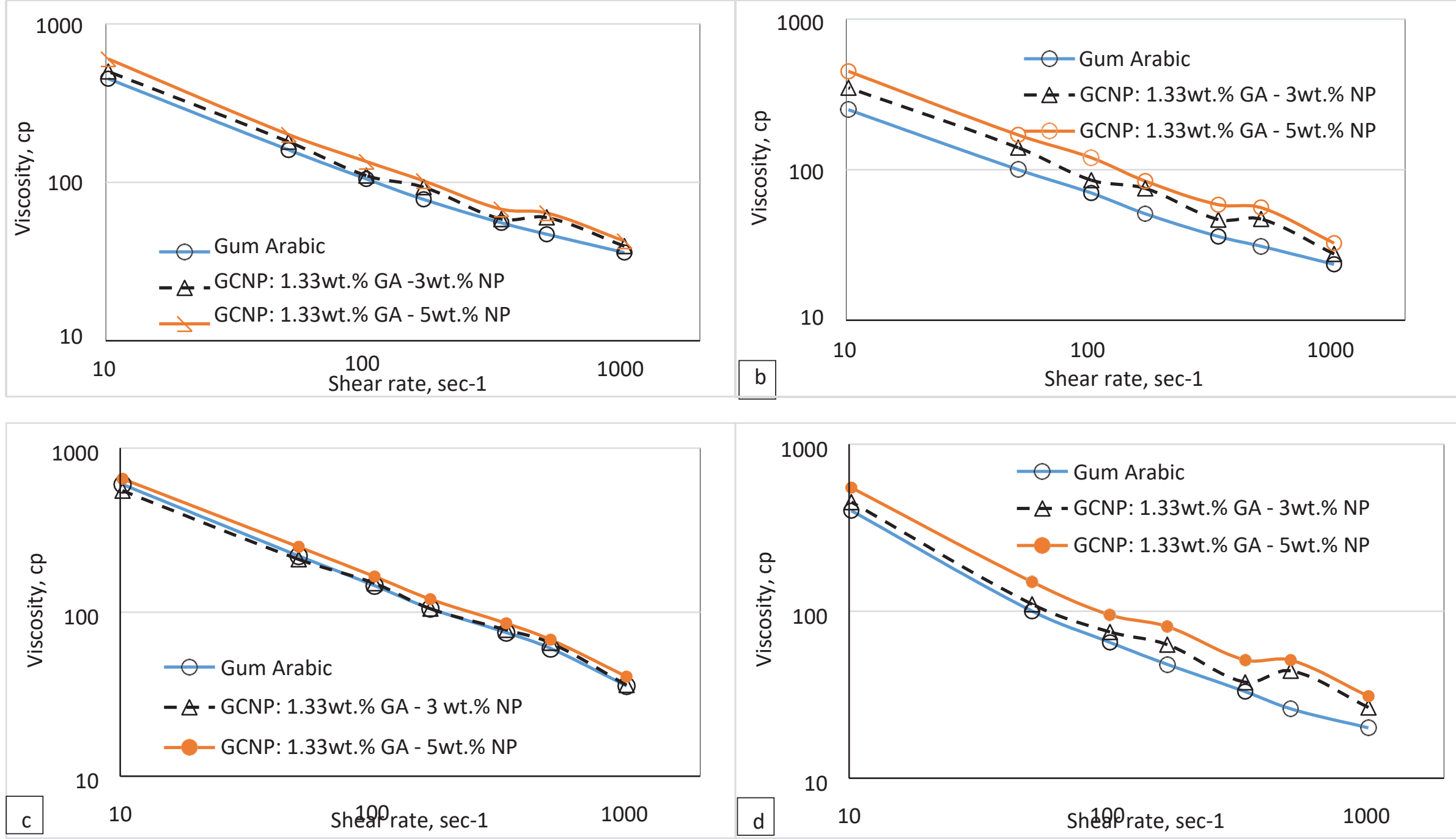

233 Figure 5 - Gum Arabic (GA) and Gum arabic nanocomposite viscosity profile (a) $25^{\circ} \mathrm{C}$ (b) $50{ }^{\circ} \mathrm{C}$ (c) $100{ }^{\circ} \mathrm{C}$ and (d) $150{ }^{\circ} \mathrm{C}$ (Orodu et al., 233 2018) 


\subsubsection{Potato Peel Starch Polymer Nanocomposite (PSPNP) Coreflooding}

The porosity and permeability estimation of core plug samples were measured using the RPT equipment. Core plugs are natural cores from the Offshore Depobelt of the Niger Delta in Nigeria. Dimensions of the cores are given in Table 2.

Table 2 - Physical properties of Core Samples

\begin{tabular}{lcccc} 
Samples & $\begin{array}{c}\text { Diameter } \\
(\mathbf{c m})\end{array}$ & $\begin{array}{c}\text { Length } \\
(\mathbf{c m})\end{array}$ & $\begin{array}{c}\text { Porosity } \\
\mathbf{( \% )}\end{array}$ & $\begin{array}{c}\text { Permeability } \\
(\mathbf{m D})\end{array}$ \\
\hline Core B2 & 3.7 & 7 & 22.58 & 291.32 \\
Core B3 & 3.7 & 7 & 26.71 & 293.11 \\
Core B4 & 3.7 & 7 & 26.7 & 293.1 \\
\hline
\end{tabular}

Cores B3 - B4 were subjected to secondary water flooding followed by PSP and PSPNP flooding (Figure 6) at ambient temperature and confining pressure of 200 psi. During the secondary water flooding, brine was injected into the cores to displace the oil to residual oil saturation. The biopolymer was first used to flood the core for the tertiary recovery process then after it was observed that no more oil could be recovered, then PSPNP $(1.0 \mathrm{wt} \%$ of Nanoparticles for B3, and 1.5 wt\% of Nanoparticles for B4) was used for the flooding to investigate if it could yield more recovery. For Core B3 (at an injection rate of $1.5 \mathrm{cc} / \mathrm{min}$ ) oil recovery ceased, and water breakthrough commenced thereby leaving some residual oil which could still be recovered. The water flood process was able to recover about $51.13 \%$ of the OOIP. This necessitated the injection of Core B3 at additional $1.5 \mathrm{cc} / \mathrm{min}$ with PSP. The biopolymer (PSP) flooding gave a total additional recovery of $5.11 \%$ of the total initial oil Place. The PSPNP flooding yielded a further incremental recovery of about $10.22 \%$ at an additional 2cc/min injection rate. From the flooding experiments carried out, during the PSPNP flooding for Core B3 - Core B4, it was observed that the combination of biopolymer and nanoparticles was able to recover $11.6 \%$, and $12.43 \%$ of the OOIP (see Table 3 for a summary of the core flooding performance). This may not be unconnected with the relatively high residual oil saturation after water flooding. It is thereby indicating the capability of biopolymer nanocomposite flooding, over and above polymer flooding. It is widely known that polymer flooding serves the sole purpose of enhancing sweep efficiency by preventing the fingering of displacement fluid through oil. After the flooding process, it was observed that from the first flooding experiment to the last flooding experiment for the PSPNP $(1.0-1.5 \mathrm{wt} \%$ of Nanoparticles) that there was an increase in the percentage recovery of the OOIP. The increase in recovered oil stems from the increase in the concentration of nanoparticle, though marginal. The summary of the core flooding results is presented in Table 2. This includes data for Core B2 not in Figure 6. Waterflooding injection rate of $7 \mathrm{cc} / \mathrm{min}$ showed elongated and increased PV injected which led to bypass of oil but essentially recovered slightly less crude oil during waterflooding. 
272 Table 3: Core flooding parameters and result for secondary and tertiary recovery (PSP and PSPNP)

\begin{tabular}{|c|c|c|c|c|c|c|c|c|c|c|c|c|c|c|}
\hline \multirow{3}{*}{$\begin{array}{c}\text { Core } \\
\text { Sample }\end{array}$} & \multirow{3}{*}{$\mathrm{S}_{\mathrm{wi}}$} & \multirow{3}{*}{$\begin{array}{c}\text { Oil } \\
\text { API } \\
\text { Gravity } \\
\text { @ } 29 \\
{ }^{0} \mathrm{C}\end{array}$} & \multirow{3}{*}{$\begin{array}{l}\mathrm{Al}_{2} \mathrm{O}_{3} \\
\text { Soln. }\end{array}$} & \multirow{3}{*}{$\begin{array}{r}\text { Starch } \\
\text { Soln } \\
\text { wt\% }\end{array}$} & \multicolumn{3}{|c|}{ Flooding rate (cc/min) } & \multicolumn{3}{|c|}{ Residual Oil Saturation $\left(\mathrm{S}_{\mathrm{or}}\right)$} & \multirow{3}{*}{$\begin{array}{l}\text { Water } \\
\text { flooding }\end{array}$} & \multirow{2}{*}{\multicolumn{2}{|c|}{$\begin{array}{c}\text { \% Recovery } \\
\begin{array}{c}\text { Incremental } \\
\text { recovery }\end{array} \\
\end{array}$}} & \multirow{3}{*}{ Total } \\
\hline & & & & & \multirow{2}{*}{$\begin{array}{c}\text { Water } \\
\text { flooding }\end{array}$} & \multirow{2}{*}{$\begin{array}{c}\text { PSP } \\
\text { flooding }\end{array}$} & \multirow{2}{*}{$\begin{array}{l}\text { PSPNP } \\
\text { flooding }\end{array}$} & \multirow{2}{*}{$\begin{array}{c}\text { Post } \\
\text { Water } \\
\text { flooding }\end{array}$} & \multirow{2}{*}{$\begin{array}{l}\text { Post } \\
\text { PSP } \\
\text { flooding }\end{array}$} & \multirow{2}{*}{$\begin{array}{l}\text { Post- } \\
\text { PSPNP } \\
\text { flooding }\end{array}$} & & & & \\
\hline & & & & & & & & & & & & $\begin{array}{c}\text { PSP } \\
\text { flooding }\end{array}$ & $\begin{array}{l}\text { PSPNP } \\
\text { flooding }\end{array}$ & \\
\hline Core B2 & 0.24 & 34.97 & 0.5 & 5.0 & 7.0 & 1.5 & 2.0 & 0.41 & 0.16 & 0.046 & 51.13 & 5.12 & 10.22 & 64.61 \\
\hline Core B3 & 0.12 & 34.97 & 1.0 & 5.0 & 1.5 & 1.5 & 2.0 & 0.43 & 0.30 & 0.193 & 46.15 & 6.86 & 11.6 & 66.47 \\
\hline Core B4 & 0.12 & 34.97 & 1.5 & 5.0 & 1.5 & 1.5 & 2.0 & 0.34 & 0.19 & 0.065 & 62.16 & 7.02 & 12.44 & 81.62 \\
\hline
\end{tabular}

274 Table 5 - Core flooding parameters and result for secondary and tertiary recovery (GA and GCNP)

\begin{tabular}{|c|c|c|c|c|c|c|c|c|c|c|c|c|c|c|}
\hline \multirow{3}{*}{$\begin{array}{c}\text { Core } \\
\text { Sample }\end{array}$} & \multirow{3}{*}{$\mathrm{S}_{\mathrm{wi}}$} & \multirow[b]{2}{*}{ Oil } & \multirow[b]{2}{*}{$\mathrm{Al}_{2} \mathrm{O}_{3}$} & \multirow[b]{2}{*}{ GA } & \multirow{2}{*}{\multicolumn{3}{|c|}{ Flooding rate (cc/min) }} & \multirow{2}{*}{\multicolumn{3}{|c|}{ Residual Oil Saturation $\left(\mathrm{S}_{\mathrm{or}}\right)$}} & \multirow{2}{*}{ Water } & \multirow{2}{*}{\multicolumn{2}{|c|}{$\begin{array}{c}\text { \% Recovery } \\
\begin{array}{c}\text { Incremental } \\
\text { recovery }\end{array}\end{array}$}} & \multirow[b]{3}{*}{ Total } \\
\hline & & & & & & & & & & & & & & \\
\hline & & $\begin{array}{l}\text { API } \\
\text { @ } 29\end{array}$ & $\begin{array}{l}\text { Soln } \\
\text { wt } \%\end{array}$ & $\begin{array}{l}\text { Soln. } \\
\text { wt } \%\end{array}$ & $\begin{array}{c}\text { Water } \\
\text { flooding }\end{array}$ & $\begin{array}{c}\text { GA } \\
\text { flooding }\end{array}$ & flogding & $\begin{array}{l}\text { Water } \\
\text { Post } \\
\text { flooding }\end{array}$ & $\begin{array}{c}\text { GAA } \\
\text { POst } \\
\text { flooding }\end{array}$ & $\begin{array}{l}\text { GCNP } \\
\text { fost } \\
\text { flooding }\end{array}$ & flooding & flogding & flocding & \\
\hline Core A & 0.22 & 34.97 & 1.33 & 5.0 & 3 & - & 0.5 & 0.42 & - & 0.36 & 46.15 & - & 7.18 & 53.33 \\
\hline Core B & 0.23 & 34.97 & 1.33 & 5.0 & 3 & - & 0.5 & 0.40 & - & 0.34 & 47.40 & - & 7.81 & 55.21 \\
\hline Core C & 0.19 & 34.97 & 1.33 & 3.0 & 3 & - & 0.5 & 0.42 & - & 0.38 & 47.96 & - & 5.61 & 53.57 \\
\hline *Core D & 0.19 & 34.97 & - & 3.0 & 3 & 0.5 & - & 0.34 & 0.32 & - & 57.89 & 2.63 & - & 60.53 \\
\hline
\end{tabular}

*After waterflooding, the core plug was flooded with Gum Arabic solution and not Gum Arabic Nanocomposite as in Core A, B, and C. 


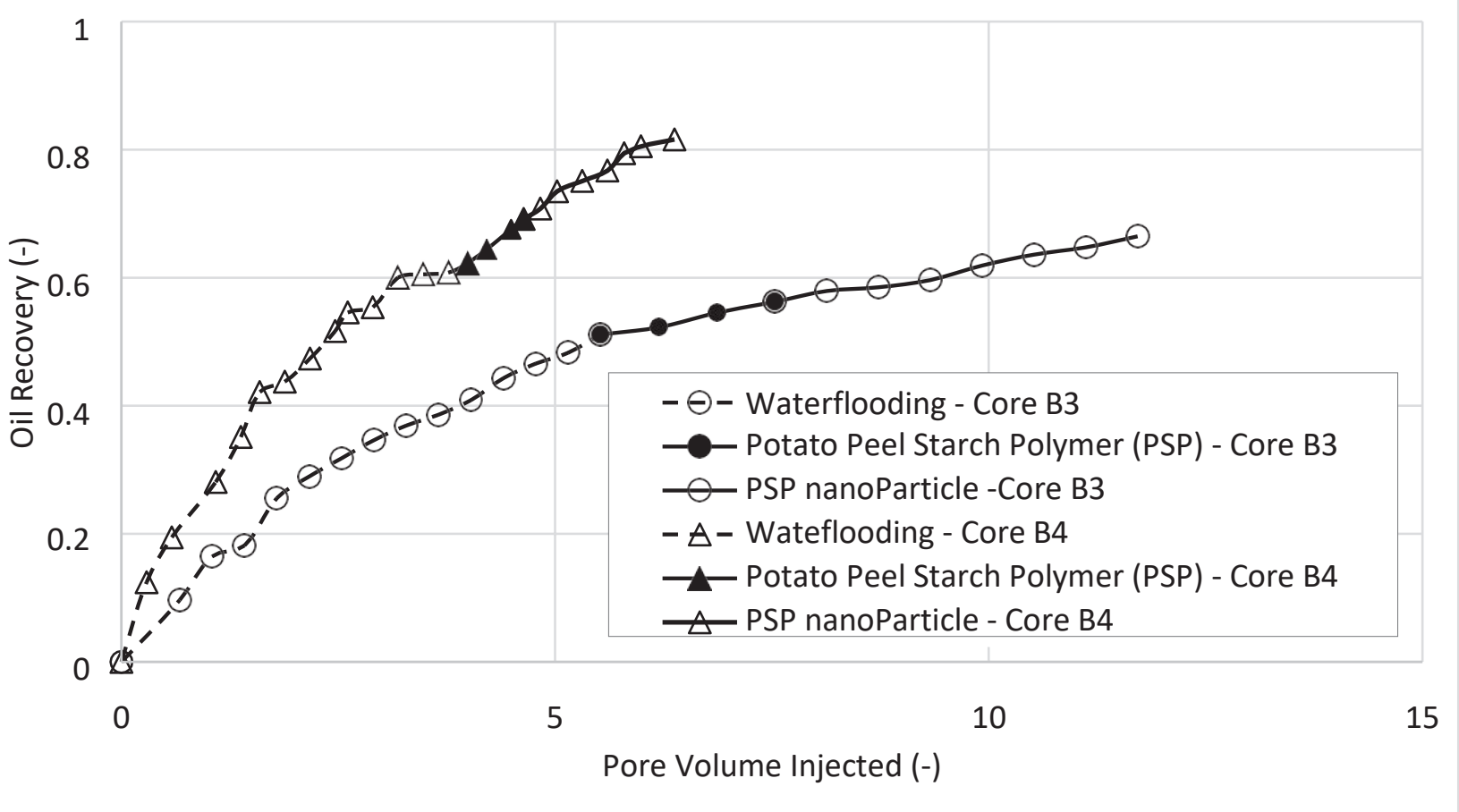

277 Figure 6 - Oil Recovery after biopolymer (PSP)and biopolymer nanocomposite (PSPNP) 278 flooding of Core B3 - B4.

\subsubsection{Gum Arabic Nanocomposite (GCNP) Core flooding}

Berea sandstone cores (natural cores from the outcrop of the Berea Formation in US.) designated as Core A, Core B, Core C and Core D were employed in the core flooding study involving GA and GCNP at ambient temperature and confining pressure of 200 psi. Table 4 shows the properties of the cores, inclusive of the impact of GA and GCNPs flooding on permeability impairment of the cores. The permeability reduction observed after post flooding can be attributed to the adsorption of nanoparticles. The concentration of GCNP and Gum Arabic are 1.33 wt.\% Gum Arabic - 5.0 wt.\% $\mathrm{Al}_{2} \mathrm{O}_{3}$ Nanoparticles - GCNPs for Core-A and Core-B, 1.33 wt.\% Gum Arabic - 3.0 wt. $\% \mathrm{Al}_{2} \mathrm{O}_{3}$ Nanoparticles - GCNPs for Core-C, and 1.33 wt.\% Gum Arabic for Core-D. Core D showed a minimal reduction in permeability due to the absence of nanoparticles and permeability reduction is due to mainly polymer adsorption. The permeability reduction is highest in cores A and B, which is flooded with GCNPs with $5 \mathrm{wt} \%$ nanoparticles. The higher the nanoparticle content, the more the permeability impairment observed. 
Table 4 - Rock Properties of the Berea cores and GCNP effect on permeability

\begin{tabular}{cccccc}
\hline $\begin{array}{c}\text { Core } \\
\text { Samples }\end{array}$ & Length & Diameter & Porosity & $\begin{array}{c}\text { Absolute } \\
\text { Permeability }\end{array}$ & $\begin{array}{c}\text { Permeability } \\
\text { (GCNP } \\
\text { flooding) } \\
(\mathrm{mD})\end{array}$ \\
\hline Core A & 6.30 & 3.7 & $18.41 \%$ & 262.3 & 125.8 \\
Core B & 6.25 & 3.7 & $18.56 \%$ & 278.8 & 115.4 \\
Core C & 6.30 & 3.7 & $17.89 \%$ & 251.7 & 173.2 \\
Core D & 6.25 & 3.7 & $17.51 \%$ & 245.0 & 223.7 \\
\hline
\end{tabular}

* Permeability of the cores as specified by Cleveland Quarries Inc. is $250 \mathrm{mD}$.

Table 5 presents a summary of results from the core flooding experiment and the associated data for the concentration of components, GA and $\mathrm{Al}_{2} \mathrm{O}_{3}$ nanoparticles. Incremental oil recovery by EOR after waterflooding was lowest for Core-D. EOR for the core was by GA and not GCNP. The result is attributed to the higher viscosity of GCNP, hence improved mobility ratio. Besides, the impact of the $\mathrm{Al}_{2} \mathrm{O}_{3}$ in GCNP due to the displacement mechanism at play gave rise to the enhanced incremental recovery by GCNP over GA. Graphical presentation of the performance is as viewed in Figure 7. The difference between incremental recovery for Core-A and Core-B, over Core-C, is glaring. Recovery from Core-A and Core-B is $39 \%$ and $28 \%$ over Core-C. The concentration of GA used for flooding Core-A and Core-B is $5 \mathrm{wt} \%$ compared to $3 \mathrm{wt} \%$ of Core-C. Consequently, permeability reduction is higher during flooding with values of $-52 \%,-59 \%,-31 \%$ and $-9 \%$ respectively for Core-A, Core-B, Core-C, and Core-D. These reductions in the core's permeability may be connected to the agglomeration of GA and the log-jamming effect of alumina nanoparticles at the pore-throat entrance of the porous medium of the cores. 


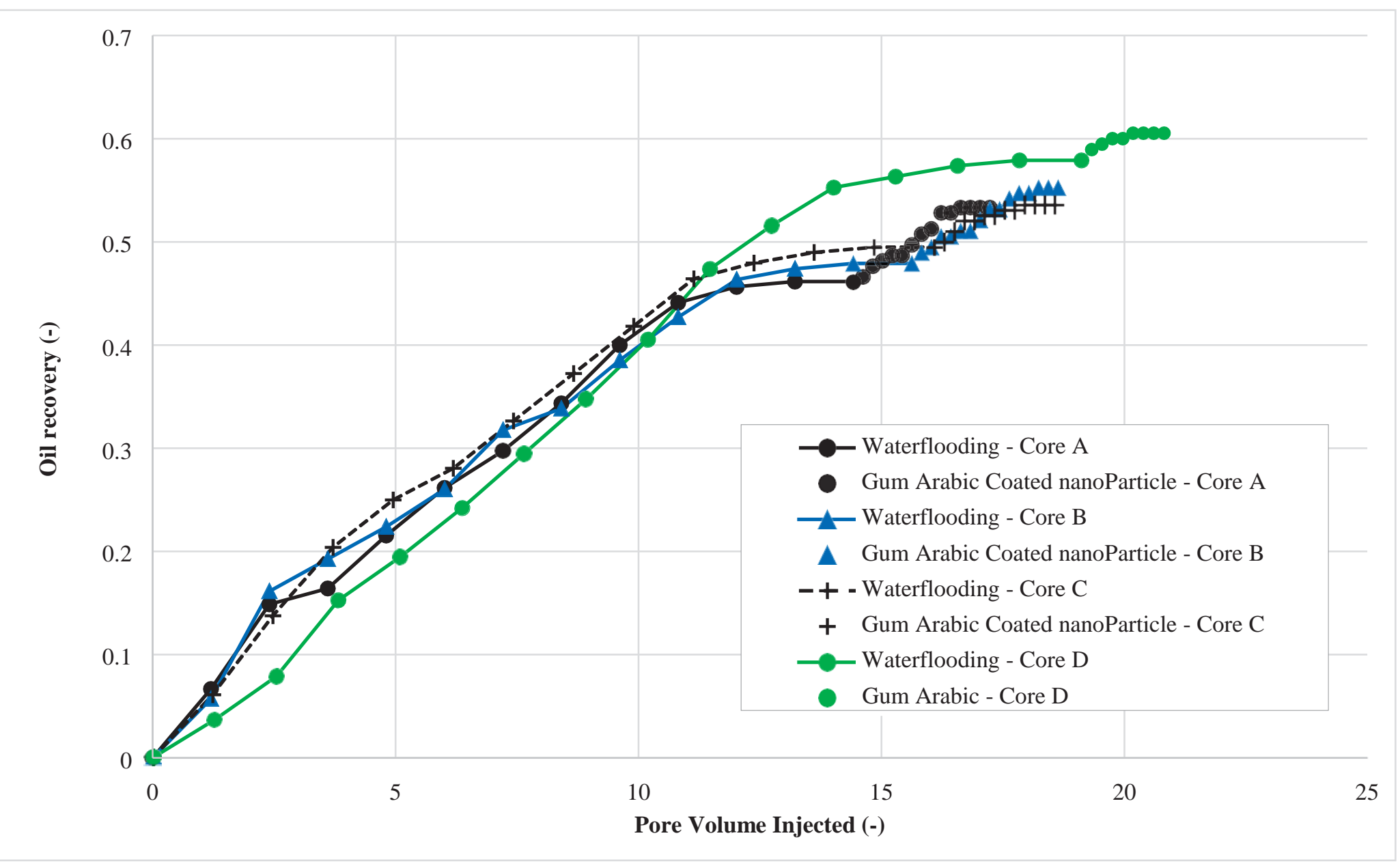

Figure 7 - Oil Recovery after waterflooding and gum arabic / gum arabic nanocomposite (GNCP) for Cores A, B, C and D (modified after Orodu et al., 2018b) 


\subsection{Discussion}

Possible petroleum reservoir temperature range, up to the defined high-temperature limit (hightemperature range of $149{ }^{\circ} \mathrm{C}-204{ }^{\circ} \mathrm{C}$ by Brujin et al., 2008) was used to model experiment conducted for effect on viscosity. Hence the investigation of viscosity at 50, 100 and $150{ }^{\circ} \mathrm{C}$. As expected, shear-thinning behaviour was observed at all fluid temperatures that were investigated. Thus, depicting non-Newtonian fluid for PSPNP and GCNP. PSPNP measured viscosity range is similar to that of Jiang et al. (2016). The viscosity trend at $500 \mathrm{C}$ for the salt concentration of $2.5 \mathrm{wt} \%$ and $5 \mathrm{wt} \%$ shows the same trend with that of Jiang et al. (2016) at a higher salt concentration. It was observed that the viscosity at $5 \mathrm{wt} \% \mathrm{NaCl}$ was lower than that of $2 \mathrm{wt} \%$. Jiang et al. (2012) stated this to be due to the reduction in interactions of the nanocomposites by the shielding effect of sodium ions. This phenomenon is asserted in Shi et al. (2012) and corroborated by the electric double layer and the decrease in the Derbye's length of the nanocomposite (Shi et al., 2013). However, this trend was reversed at $100{ }^{\circ} \mathrm{C}$ and maintained at $150{ }^{\circ} \mathrm{C}$ as was the case at $50{ }^{\circ} \mathrm{C}$. Again, the effect of $\mathrm{NaCl}$ at $50{ }^{\circ} \mathrm{C}$ was adequately accounted for in literature. The inverse relationship of viscosity with temperature is also attributed to change from particulate network to molecular network (gel network nature) according to Herrera et al. (2017). This trend aligns with the reduction of hydrodynamic diameter with increasing temperature and trends in storage modulus, loss modulus and complex viscosity. The viscosity profile at $150{ }^{\circ} \mathrm{C}$ may be due to the perceived break of inter and intramolecular bonds of the nanocomposite and after that an increase of starch-water hydrogen bond (Herrera et al., 2017; Shi et al., 2013). In addition, cations affect the starch structure and inhibit gelatinisation temperature (Bergthaller et al., 1999; Oosten, 1982). Thus, Al2O3 nanoparticles affect the viscosity of PSPNP.

No clear explanation exists for the viscosity behaviour at $150{ }^{\circ} \mathrm{C}$ based on the knowledge of the authors. However, endothermic peak (transition) is linked to the gelatinisation of native starch that occurs within 50 to $80{ }^{\circ} \mathrm{C}$ (Herrera et al., 2017; LeCorre et al., 2012). One peak was observed for starch polymer but two peaks for starch-nanocrystal. The first peak for starch nanocrystal had a higher temperature and explained by the authors as due to the decline in the plasticiser, a perfect crystal and increase in crystallinity. A conclusion may be drawn for this study on the viscosity behaviour of not only PSPNP but also GCNP. Is it connected to the high energy (or temperature) to achieve endothermic transition as the case of starch? More investigation is required for this.

Surface-active agent of polymer-nano and emulsion formation has impacted oil recovery by further incremental recovery (Alvarez et al., 2012; Foster et al., 2014; Saleh et al., 2005; Yoon et al., 2012; Yong, 2015). Gum arabic has been known to be an active surface modifier with the formation of the stable oil-water emulsion and hence lowering IFT as widely known and stated by Gashua et al. (2016) and Zhang et al. (2007). For the emulsifying (surface-active nature) property of gum Arabic, the incremental recovery should have been higher. This brings to fore the report by Gashua (2016) on GA from Acacia senegal tree in Nigeria of the increase in hydrodynamic radius (i.e. agglomeration by electrostatic attraction) in deionised water. The solution lies in future studies by using stabilisers in preventing agglomeration like that of Gashua (2016) who used 0.5M NaNO 3 solution and Li et al. (2009) using 6M Urea. Besides, GA from Nigeria based on the samples evaluated by Gashua et al. (2016) forms stable oil-inwater emulsions as regards to the measurement and consistency of droplet size within a week. The investigation of IFT of gum arabic nanocomposite is essential for the knowledge on its functionality as an EOR agent with surface-active capability.

For the actual and fair comparison of incremental recovery from potato starch and gum arabic $\mathrm{Al} 2 \mathrm{O} 3$ nanocomposite, sand pack tube as the porous media instead core plug seems the most 
appropriate. The aim is to guarantee relatively uniform and approximately constant porosity, permeability and sandstone grain size. Thereby enabling multiple experimental runs with only the change of sand grains at low cost. Sticking to core plugs as the test medium ensures that the experiment can be conducted under reservoir conditions. However, the evaluation of porethroat bridging as a consequence of nanocomposite and pore throat size, and nanocomposite agglomeration is possible. Assessment through TEM/SEM and the monitoring of both the concentration of nanocomposite and core plug effluent are means of studying pore bridging and the recovery efficiency for a fair comparison of the different polymer nanocomposites.

Reduction in permeability during GCNP flooding is a sign of nanocomposite retention. Mechanical entrapment by the sheer size of the nanocomposite may not be the direct cause since pore-throat radius from the approximation of Winland formula (Hartmann and Coalson, 1990; Martins et al., 1997) if applicable is $\approx 11,000 \mathrm{~nm}$ for the Berea cores. The $\mathrm{Al}_{2} \mathrm{O}_{3}$ nanoparticles size is $30-60 \mathrm{~nm}$. Hence, the problem may be by the agglomeration of nanocomposites as earlier enumerated for gum arabic molecular association if non-swelling clay is absent in the cores. Thus, log-jamming is the primary process of nanocomposite retention.

Potato starch as used in this study is from the potato peel and thus ensures waste management. The availability for large scale deployment for EOR is subject for concern compared to gum Arabic. The trees, Acacia senegal and Acacia seyel from which gum Arabic comes off is formed in the wild and also cultivated. It spreads across $8000 \mathrm{~km}$ of the Sahel in Africa with a width of $15 \mathrm{~km}$ (Green Planet, 2010). This is known as the gum Arabic (or green belt) of Africa. Gashua (2016) reported the price of a tonne of raw GA as USD 1,356 in 2011. The authors of this work purchased a $\mathrm{kg}$ for USD 3.862 in 2017. Hence, gum arabic is readily available. Elmquist et al. (2005) stated that Sudan is the world's largest producer of gum arabic, accounting for $80-90 \%$ of the world supply as of that time. Nigeria follows Sudan on the top producers of GA. Export from Sudan totalled up to 55,000 tonnes in 2010 (Martelli, 2010).

\section{Conclusion}

Core-flooding experiment, rheological tests were carried out to evaluate the application of biopolymer nanocomposities in enhanced oil recovery (EOR). The following conclusions are drawn from the study:

- $\quad$ Potato Peel Starch Nanocomposite (PSPNP) showed good viscosifying efficiency and exhibited strong shear thinning behaviour when compared to another biopolymer.

- $\quad$ Salinity did not show any significant effect on the biopolymer because of its non-ionic nature. The PSPNP was tested against temperature and showed stability up to $120^{\circ} \mathrm{C}$ without loss of viscosity at increasing shear rate.

- $\quad$ Core-flooding experiment was conducted on core samples to study the recovery capability of PSPNP in porous media. The physical properties of the core samples were collected to assume a perfect reservoir condition. There was an incremental recovery from $7.02-12 \%$ of the initial oil in place after carrying the conventional water-flooding process.

- The PSPNP was injected to recover more oil that may have been by-passed by waterflooding giving an Incremental recovery from 2-9\%. PSPNP samples produced were used in flooding cores at varying nanoparticles $\left(\mathrm{Al}_{2} \mathrm{O}_{3}\right)$ concentration $(0.5 \mathrm{wt} \%$, $1.0 \mathrm{wt} \%, 1.5 \mathrm{wt} \%)$.

- $\quad$ EOR by Gum Arabic Alumina Nanocomposite showed incremental recovery from 5.16 $-7.18 \%$ over and beyond the secondary recovery scheme of waterflooding. In 
addition, it was evident that the Gum Arabic nanocomposite outperformed Gum Arabic polymer flooding.

\section{Acknowledgement}

The authors would like to thank the management of Covenant University for providing the needed facilities to carry out this research.

\section{Conflict of Interest}

The authors have no conflict of interest to declare

\section{Reference}

1. Abidin, A. Z., Puspasari, T., \& Nugroho, W. A. (2012). Polymers for Enhanced Oil Recovery Technology. Procedia Chemistry, 4, 11-16.

2. Alvarez, N.J., Anna, S.L., Saigal, T., Tilton, R.D., \& Walker, L.M. (2012) Interfacial dynamics and rheology of polymer-grafted nanoparticles at air-water andxylene-water inter-faces, Langmuir, 28:8052-63.

3. Bergthaller, W., Witt, W., \& Goldau, H.P. (1999) Potato starch technology. StKrke (Starch), 51: 235-242.

4. Bidzinska, E., Michalec, N., Pawcenic, D. (2015) Effect of Thermal Treatment on Potato Starch Evidenced by EPR, XRD and Molecular Weight Distribution, Magn. Reson. Chem., 53:1051-1056.92016

5. Buffo, R.A, Reineccius, G.A. \& Oehlert, G.W. (2001) Factors affecting the emulsifying and rheological properties of gum Acacia in beverage emulsion. Food Hydrocolloids, 15(1): 53-66.

6. DeBrujin G., Skeates, C., Greenaway, R., Harrison, D., Parris, M., James, S., Mueller, F., Ray, S., Riding, M., Temple, L., \& Wutherich, K. (2008) High- Pressure, High Temperature Technologies, Schlumberger's Oilfield Review Autumn Schlumberger Oilfield Review, 20(3):46-53.

7. Degen, P., Vidoni, O. \& Rehage, H. (2012) Colloid chemical properties of heat-treated gum Acacia. In J.F. Kennedy, G.O. Phillips and P.A Williams (Eds.), Gum Arabic. Special ed. Cambridge: RSC Publishing, UK, pp. 239-248

8. Elmqvist, B., Olsson, L., Elamin, E. and Warren, A. (2005) A traditional agro forestry system under threat: An analysis of gum Arabic market and cultivation in the Sudan. Agroforestry systems, 64: 211-218.

9. Foster, L.M., Worthen, A.J., Foster, E.L., Dong, J., Roach, C.M., Metaxas, A.E., et al. (2014) High interfacial activity of polymers "grafted through" functionalized iron oxide nanoparticle clusters, Langmuir, 30:10188-96

10. Gashua, I.B. (2016) An investigation of the molecular structure, composition and biophysical properties of gum Arabic, Dissertation, University of Wolverhampton, UK.

11. Gashua, I.B., Williams, P.A., \& Baldwin, T.C. (2016) Molecular characteristics, association and interfacial properties of gum Arabic harvested from both Acacia senegal and Acacia seyal, Food Hydrocolloids, 61:514-522;

12. Gilbert, R.G., Gidley, M.J., Hill, S., Kilz, P., Rolland-Sabate, A., Stevenson, D.G., Cave, R.A. (2010) Characterizing the Size and Molecular Weight Distribution of Starch: Why it is Important and Why it is Hard, Cereal Foods World, 55(3): 139-143.

13. Green Planet (2010). Great green wall of Africa to halt Sahara, [Online] (Accessed 21 $1^{\text {st }}$ January, 2019) Available at: < http://www.greenplanet.com/great-green-wall-of-africato-halt-sahara/> 
14. Harding, S.E., Adams, G.G., Gillis, R.B. (2016) Molecular Weight Analysis of Starches: Which Technique, Starch/Starke, 68:1-8.

15. Hartmann, D. J., \& Coalson, E. B. (1990) Evaluation of the Marrow Sandstone in the Sorrento Field, Cheyenne Company, Colorado, Rocky Mountain Association of Geologists, pp. 91-100.

16. Hendraningrat, L. Li, S., \& Torsaeter, O. (2013a) Enhanced Oil Recovery of LowPermeability Berea Sandstone through Optimized Nanofluids Concentration, Paper SPE 165283 presented at the SPE Enhanced Oil Recovery Conference held in Kuala Lumpur, Malaysia, 2-4 July 2013.

17. Hendraningrat, L., Li, S., \& Torsaeter, O. (2013b). A Coreflood Investigation of Nanofluid Enhanced Oil Recovery. Journal of Petroleum Science and Engineering, 111, 128-138.

18. Herrera, M.P., Vasanthan, T., \& Chen, L. (2017) Rheology of starch nanoparticles as influenced by particle size, concentration and temperature, Food Hydrocolloids, 66: 237-245.

19. Hu, Z., Haruna, M., Gao, H., Nourafkhan, E., \& Wen, D. (2017.). Rheology of Partially Hydrolyzed Polyacrylamide Seeded by Nanoparticles, Ind. Eng. Chem. Res., 56:34563463

20. Jiang, S., Liu, C., Han, Z., Xiong, L., \& Sun, Q. (2016) Evaluation of rheological behavior of starch nanocrystals by acid hydrolysis and starch nanoparticles by selfassembly: A comparative study, Food Hydrocolloids, 52: 914-922.

21. Ju, B., Fan, T. (2009) Experimental Study and Mathematical Model of Nanoparticle Transport in Porous Media, Powder Technology, 192(2): 195 - 202.

22. LeCorre, D., Bras, J., \& Dufrense, A. (2012) Influence of native starch's properties on starch nanocrystals thermal properties, Carbohydrate Polymers, 87:658-666.

23. Lewandowska K. (2006) Comparative studies of rheological properties of polyacrylamide and partially hydrolyzed polyacrylamide solutions. J. Appl. Polym. Sci., 103: 2235-2241.

24. Li, S., Hendraningrat, L., \& Torsaeter, O. (2013). Improved Oil Recovery by Hydrophilic Silica Nanoparticles Suspension: 2-Phase Flow Experiment Studies. Paper IPTC-16707 presented at the International Petroleum Technology Conference, 26-28 March, Beijing, China.

25. Li, X., Fang, Y., Al-Assaf, S., Phillips, G.O., Nishinari, K. \& Zhang, H. (2009) Rheological study of gum Arabic solutions: Interpretation based on molecular selfassociation. Food Hydrocolloids, 23: 2394-2402.

26. Maghzi, A, Mohammadi, S., Ghazanfari, M.H., Kharrat, R. Masihi, M. (2012) Monitoring Wettability Alteration by Silica Nanoparticles during Water Flooding to Heavy Oils in Five-Spot Systems: A Pore-Level Investigation. Experimental Thermal and Fluid Science 40 (2012): 168-176.

27. Mahendran, T., Williams, P.A., Phillips, G.O., Al-Assaf, S. \& Baldwin, T.C. (2008) New insights into the structural characteristics of the arabinogalactan-protein (AGP) fraction of gum Arabic. J. Agric. Food Chem., 56: 9269-9276.

28. Martin, A. J., Solomon, S. T., \& Hartmann, D.J. (1997) Characterization of petrophysical flow units in carbonate reservoirs, AAPG Bulletin, 81(5): 734-759.

29. Mauryu, N.K., Kushwaha, P., Mandal, A. (2017) Studies on Interfacial and Rheological Properties of Water Soluble Polymer Grafted Nanoparticle for Application in Enhanced Oil Recovery, Journal of Taiwan Institute of Chemical Engineers, 70:319 - 330.

30. Mertelli, S. (2011) Gum arabic a potential cure for sudanese ills., [Online] (Accessed 22 ${ }^{\text {nd }}$ January, 2019) Available at: https://phys.org/news/2011-11-gum-arabic-potentialsudanese-ills.html 
31. Ogolo, N. A., Olafuyi, O. A., \& Onyekonwu, M. O. (2012). Enhanced Oil Recovery Using Nanoparticles. SPE Saudi Arabia Section Technical Symposium and Exhibition (pp. 1-9). Al-Khobar: Society of Petroleum Engineers.

32. Oosten, B.J. (1982) Tentative hypothesis to explain how electrolytes affect the gelatinization temperature of starches in water. StKrke (Starch), 34: 233-239.

33. Orodu, O.D., Orodu, K.B., Afolabi, R.O., Eboh, D.A. (2018a) Rheology of Gum Arabic Polymer and Gum Arabic Coated Nanoparticle for Enhanced Recovery of Nigerian Medium Crude Oil under Varying Temperatures, Data in Brief. 19(2018): 1773-1778.

34. Orodu, O.D., Orodu, K.B., Afolabi, R.O., Eboh, D.A. (2018b) Dataset on Experimental Investigation of Gum Arabic Coated Alumina Nanoparticles for Enhanced Recovery of Nigerian Medium Crude Oil, Data in Brief. 19:475-480.

35. Osamah, A. A., Khaled, M. M., \& Yousef, A. H. (2015). Experimental study of Enhanced-Heavy-Oil Recovery in Berea Sandstone Cores by Use of Nanofluids Applications. SPE Reservoir Evaluation \& Engineering 18(3), 1-13.

36. Pittman, E. D. (1992) Relationship of Porosity and Permeability to Various Parameters Derived from Mercury Injection-Capillary Pressure Curves for Sandstone. AAPG Bulletin 76(2):191-198.

37. Renard, D., Lavenant-Gourgeon, L., Ralet, M.C. and Sanchez, C. (2006) Acacia senegal gum: continuum of molecular species differing by their protein to sugar ratio, molecular weight, and charges. Biomacromolecules, 8, pp. 2637-2649

38. Rodriguez, E., Roberts, M. R., Yu, H., Huh, C., \& Bryant, S. L. (2009) Enhanced Migration of Surface-Treated Nanoparticles in Sedimentary Rocks, SPE 124418 presented at the 2009 SPE Annual Technical Conference and Exhibition, New Orleans, LA, 4-7 October.

39. Rousteai, A., Moghadasi, J., Bagherzadeh, H., \& Shahrabadi, A. (2012). An Experimental Investigation of Polysilicon Nanoparticles' Recovery Efficiencies through Changes in Interfacial Tension and Wettability Alteration. SPE Paper 156976 presented at the SPE International Oilfield Nanotechnology Conference and Exhibition, 12-14 June, Noordwijk, The Netherlands.

40. Saha, R., Ramgopal, V. S., \& Tiwari, P. (2018). Silica Nanoparticle Assisted Polymer Flooding of Heavy Crude Oil: Emulsification, Rheology, and Wettability Alteration Characteristics. Industrial and Engineering Chemistry Research, 57, 6364-6376.

41. Saleh, N., Sarbu, T., Sirk, K., Lowry, G.V., Matyjaszewski, K., \& Tilton, R.D. (2005) Oil-in-water emulsions stabilized by highly charged polyelectrolyte-grafted silica nanoparticles. Langmuir, 21:9873-8

42. ShamsiJazeyi, H., Miller, C. A., Wong, M. S., Tour, J. M., \& Verduzco, R. (2014). Polymer-Coated Nanoparticles for Enhanced Oil Recovery. Journal of Applied Polymer Science, 131(15), 1-13.

43. Sharma, T., Sanwai, J.S. (2017) Silica Nanofluids in Polyacrylamide with and without Surfacant: Viscosity, Surface Tension, and Interfacial Tension with Liquid Paraffin, Journal of Petroleum Science and Engineering, 152: 575 - 585.

44. Shi, A.M., Li, D., Wang, L., \& Adhikari, B. (2012) The effect of $\mathrm{NaCl}$ on the rheological properties of suspension containing spray dried starch nanoparticles, Carbohydrate Polymers, 90: 1530-1537.

45. Shi, A.M., Li, D., Wang, L., \& Adhikari, B. (2013) Suspension of vacuum-freeze dried starch nanoparticles: Influence of $\mathrm{NaCl}$ on their rheological properties, Carbohydrate Polymers, 44:782-790.

46. Sun, X., Zhang, Y., Chen, G., \& Gai, Z. (2017) Application of Nanoparticles in Enhanced Oil Recovery: A Critical Review of Recent Progress, Energies 10(3): 345 
47. Taiwo, O., Olafuyi, O.A. (2015) Surfactant and Surfactant-polymer Flooding for Light Oil: A Gum Arabic Approach, Petroleum and Coal, 57(3): 205 -215.

48. Tan, C.T. (2004) Beverage emulsions. In Frieberg, S.E., Larsson, K. and Sjoblom, J. (eds.) Food Emulsions. 4th ed. CRC Press: Boca, pp. 485-524.

49. Yong, X. (2015) Modeling the assembly of polymer-grafted nanoparticles atoil-water interfaces. Langmuir, 31:11458-69.

50. Yoon, K.Y., Li, Z., Neilson, B.M., Lee, W., Huh, C., Bryant, S.L., et al. (2012) Effect of adsorbed amphiphilic copolymers on the interfacial activity of superparamagnetic nanoclusters and the emulsification of oil in water. Macromolecules, 45:5156-7.

51. Yousefvand, H., \& Jafari, A. (2015). Enhanced Oil Recovery using Polymer/nanosilica. Procedia Material Science, 565-570.

52. Yu, J., Berlin, J. M., Lu, W., Zhang, L., Kan, A. T., Zhang, P., . . . Tomson, M. B. (2010). Transport Study of Nanoparticles for Oil Field Application. SPE International Conference on Oilfield Scale (pp. 1-16). Aberdeen: Society of Petroleum Engineers.

53. Zhang, H., Shan, G., Liu, H., \& Xing, J. (2007) Surface Modification of $\gamma$-Al2O3 Nanoparticles with Gum Arabic and its Applications in Adsorption and Biodesulfurization, Surface and Coatings Technology, 201:6917-6921. 